Anja Mrak

\title{
Popculture in postcolonial literature Motifs of popular culture in Arundhati Roy's The God of Small Things and Eden Robinson's Monkey Beach
}

The term "postcolonial literature” in its broader sense encompasses works originating in countries that were in the past under European rule; however, in its narrower sense, it refers to texts that confront the problematics of (de)colonisation, independence, and history. ${ }^{1}$ According to Ashcroft, Griffiths, and Tiffin, the shared feature of all postcolonial literatures is ,that they emerged [...] out of the experience of colonisation and asserted themselves by foregrounding the tension with the imperial power, and by emphasising their differences from the assumptions of the imperial centre" [1989:2].

In an effort to counterpoint colonial discourse, authors of postcolonial literary works employ a range of textual strategies, such as the use of specific themes and motifs, the parody of the Western literary canon, the transformation of European genres and forms, hybridity, innovative techniques, and native literary forms. These are seen as dialogic and heteroglossic, and "serve to liberate the subject from the power of hegemonic language" as utilised by the coloniser [Goodman 2004: 62]. The famous phrase "the Empire writes back to

1 Postcolonial literatures include: „literatures of African countries, Australia, Bangladesh, Canada, Caribbean countries, India, Malaysia, Malta, New Zealand, Pakistan, Singapore, South Pacific Island countries, and Sri Lanka” [Ashcroft, Griffiths, and Tiffin 1989: 2]. 
the Centre", coined by Salman Rushdie, embodies the core concern of postcolonial works, namely their focus on revealing and appropriating the views and images of history, society, and people under colonial rule, superimposed upon them by colonisation and imperialism. „In the last decades of the twentieth century, processes of decolonisation opened the meaning-making powers of empire to scrutiny, as a part of large-scale effort to decolonise knowledge, history, and human relations" [Pratt 2008: 3].

Literature is an important "contact zone" where "transculturation" takes place, to borrow Mary Louise Pratt's terms. She defines contact zones as „spaces where disparate cultures meet, clash, and grapple with each other, often in highly asymmetrical relations of domination and subordination" [2008: 7]. The encroachment of the language of globalised popular culture on postcolonial texts and its interaction with the traditional culture of the author can also be read as one of the devices for deconstructing imperialist discourse, whereby the question of the contact zone is openly addressed. Popular culture motifs might be seen as the intrusion of the Other into the text, symbolically representing the processes of globalisation and the tensions arising between the two cultures. Elements of popular culture bear a strong ideological charge and have the potential to subvert the accepted notions of the centre and the margin. Here I focus on the function and implications of the language of popular culture in two texts: Monkey Beach (2000) by Canadian First Nations writer Eden Robinson and The God of Small Things (1997) by Indian author Arundhati Roy. Both novels are replete with images of popular culture which stand for the discourse and impact of colonisation and in turn form a stark contrast with the native culture and disrupt the narrative flow. The two authors exercise the concepts of the contact zone and transculturation by juxtaposing native and popular cultures; however, they render the subject in different ways.

Arundhati Roy's The God of Small Things was published in 1997, the year when India celebrated its $50^{\text {th }}$ anniversary of independence, to immediate worldwide acclaim. The novel is an indictment of on-going social and political issues in India: the cast system, patriarchy, and neocolonialism. Globalisation is also a looming presence in the novel, manifest 
in popular culture and icons of mass consumption and in the influence these exert on postcolonial India. Roy skilfully intertwines the public and private spheres in the intimate story of two star-crossed lovers Velutha and Ammu and her twin daughter and son Rahel and Estha, all of whose lives are tragically destroyed when they transgress social boundaries.

Global capitalism and the power of authority are critiqued through the quintessential image of popular culture-Coca-Cola, a beverage which in the language of popular culture represents an idyllic home environment, parties with friends, and magical Christmas, that is, a site of security and mutual trust. But for Estha bottled drinks are filled to the brim with fear and abuse, considering he is sexually harassed by a man selling drinks at the cinema. This foreshadows the police station episode, when he is again given a cold drink: „[...] Esthappen Yako finished his free bottle of fizzed, lemon-flavored fear. [...] He would be given another bottle soon (free, fizzed fear)" [Roy 1997: 105]. At the story's climax-when Velutha, a member of the lowest caste of untouchables, is brutally beaten by the police in front of the twins on false accusations that he kidnapped the children and attempted to rape Ammu-Rahel and Estha are, as previously mentioned, brought to the police station and given two Coca-Colas. The slogan Estha notices at the very outset of the novel-, a red ice-box that said rather sadly Things go better with Coca-Cola” [1997: 62] — changes into „bottled Fear for Estha. Chilled. Fizzed. Sometimes Things went worse with Coca-Cola” [1997: 313], when he is forced to falsely testify against Velutha. The inverted advertising slogan, Lutz points out, signifies a system that does not respect basic human rights, and at the same time shows how objects of mass consumption cannot satisfy human needs [2009: 64]. The subverted consumer symbol points to the rigid power structures and devalued human relations. Baby Kochamma, Ammu's aunt, manipulates Estha to falsely accuse Velutha lest he, his sister, and their mother are sent to prison. Baby Kochamma betrays the children's trust while the children are „[d] renched in Coca-Cola” [Roy 1997: 315]. „The image crated by the advertising slogan of Coca-Cola presents the soft drink as a comforting object capable of making things better, while 
the violent and destructive events that accompany Rahel and Estha's consumption of it not only undermine its commercial image but also demonstrate how objects of consumption hold out false promises of fulfilment" [Lutz 2009: 64]. Roy exposes the imagery associated with Coca-Cola as superficial and as opposed to the ideas that it supposed to uphold and links it to the global modes of exploitation.

In a similar vein, other images of popular culture are employed to criticise a contemporary society wholly devoid of genuine human relations. As previously discussed, Baby Kochamma struggles to sustain the current social order-she is a member of the upper castein a manner that pertains to capitalist ideology, paying no regard to the suffering she inflicts upon the children and their mother. Baby Kochamma's notion of superiority is fostered and fortified by the globalised culture enacted through her TV set:

Baby Kochamma had installed a dish antenna on the roof of the Ayemenem house. She presided over the World in her drawing room on satellite TV. The impossible excitement that this engendered in Baby Kochamma wasn't hard to understand. It wasn't something that happened gradually. It happened overnight. Blondes, wars, famines, football, sex, music, coups d'état - they all arrived on the same train. [...] now whole wars, famines, picturesque massacres and Bill Clinton could be summoned up like servants. And so, while her ornamental garden wilted and died, Baby Kochamma followed American NBA league games, one-day cricket and all the Grand Slam tennis tournaments. On weekdays she watched The Bold and The Beautiful and Santa Barbara [Roy 1997: 27].

The feeling that she has the whole world at her fingertips only enhances her (already existing) notions of superiority and supremacy, which later set in motion a train of tragic events. Baby Kochamma, Lutz notes, is subjected to the slow process of dehumanisation and gradually she sinks into simplified presentations of the capitalist reality, and it is no surprise that she is drawn most to programmes depicting violence and brutality [2009: 60]. She becomes ,interpellated and twisted [... by global (American) culture, which she pulls into her heart via satellite dish that feeds her TV" [Fox 2002: 42]. The TV set on the one hand be- 
comes a contact zone, unravelling the foreign world to the Indian spectator, but on the other it exemplifies the degradation of human relations and severing of family ties in the tight grip of global capitalism.

The film The Sound of Music similarly serves to foreground the contagion of globalised popular culture in a non-Western environment. Ammu's brother Chacko describes the film as „an extended exercise in Anglophilia" [Roy 1997: 55]. The twins adore it; however, the film instils in them the colonial notion of white supremacy, which is further substantiated by the visit of their cousin Sophie Mol-Chacko's English daughter. Watching the film, Estha leads an imaginary conversation with the main character, Captain von Trapp: „Are they [Rahel and Estha] clean white children? No. (But Sophie Mol is). [... 'Then I'm sorry, Capitan von Clapp-Trapp said. 'It's out of the question. I cannot love them" [1997: 106-107]. The feeling of inferiority is only intensified when the rest of the family conspicuously favour Sophie Mol over the twins, who interpret the situation thusly: „Littleangels were beach-coloured and wore bellbottoms. Littledemons were mudbrown [...]. And if you cared to look, you could see Satan in their eyes" [1997: 179]. Here Roy implicates globalised pop culture in spreading a negative image when transposed to a different cultural environment and in sustaining the processes of colonisation. According to Lutz, the film effectively demonstrates ,the process by which the children internalise the racist, neocolonial ideals that view them as inferior to white Europeans" [2009: 70]. The contact zone is in this instance perceived as a site of extreme injustice, while popular culture functions as a tool of neocolonialism.

Where Arundhati Roy employs elements of popular culture to expose the impact of neocolonialism on contemporary India, Eden Robinson's Monkey Beach presents the amalgamation of the Native and Western cultures as inevitable in the contemporary world, and sees this process as both natural and necessary as well as mutually enriching. Images of popular culture address the issue of constructed identity or hybridity as elaborated by Homi Bhabha. ${ }^{2}$ The concept of

2 See: H. Bhabha [1994], The Location of Culture, Routledge, London. 
hybridity does not merely encompass a reciprocal exchange between two cultures, but refers to "the creation of new transcultural rather than multicultural (crossing and fertilising rather than fragmented) forms within the space produced by colonisation" [Wisker 2007: 189]. Their marked difference in portraying popular culture notwithstanding, both novels scrutinise the legacy of colonialism. Monkey Beach chronicles Lisa's personal trauma, her search for identity, and the inherent clash between the native and white cultures, revealing a much larger issue of the mistreatment of the First Nations in Canada, especially in the framework of the residential school system, which served as a means of colonisation and subordination. Robinson celebrates organic hybridity, but condemns the forced assimilation executed in residential schools for First Nations children.

Monkey Beach describes the coming-of-age experiences of Lisa and her physical and spiritual quest to find her brother, who is lost at sea. It takes place within the Haisla community-one of the First Nations in Canada. Lisa is torn between two worlds, traditional and Western, and the processes of hybridisation and merging of both cultures continue throughout the novel and determine Lisa's identity formation. Robinson examines the processes of transculturation in the light of globalisation and shared geographical space occupied by native peoples and settlers' descendants.

The concept of hybrid identity is clearly visible in Lisa's uncle Mick and her grandmother Ma-ma-oo. They are the two people who have the biggest impact on Lisa and act as her teachers and guides to the native culture. Though deeply rooted in traditional ways of living, they are nonetheless open to the modern world, which they embrace with utmost curiosity. Agnes Kramer-Hamstra echoes this by saying that „Robinson eschews an ethnocentric focus on „authenticity” through a portrayal of her characters that shows them as a part of media-driven popular culture" [2009: 115].

The fusion of the popular and traditional is, for example, apparent when Lisa and Ma-ma-oo prepare salmonberries and thimbleberries according to a traditional recipe, after which they watch popular American TV shows The Young and The Restless, All My Children, and 
Dynasty: „We spent the last of good weather tromping through bushes, picking berries and watching „Dynasty,” with Ma-ma-oo shouting advice to the wayward Alexis" [Robinson 2000: 161]. Though firmly grounded in traditional practices, Ma-ma-oo teaches Lisa the importance of being open to other cultures and to accept the transculturation and hybridity of the modern world. Written in the mode of magical realism, the novel also fuses natural and supernatural elements, related mostly to Lisa's "gift"- she is burdened with terrifying visions of future tragedies and is able to sense the supernatural. Popular culture is even bound up with the supernatural, which enters the otherwise realist narrative flow: „The porch groaned under the weight of something that sounded like it was dragging itself across the wood. The TV flickered, and beneath „Dynasty”'s music, I could hear laughter and singing. [...] The strange sounds on the porch stopped" [2000: 187].

Lisa's uncle Mick is a political activist and fighter for Native Americans' rights, but also an avid Elvis fan. His political stance on the mistreatment of Aboriginal peoples in Canada does not interfere with his love for popular music. He listens to his music constantly, copies his haircut, is glad that Lisa is named after Elvis's daughter, and becomes depressed upon his death: „Mick took off for almost a month and we later learned he'd driven to Graceland" [2000: 63]. His hybrid identity is best portrayed when Lisa sees Mick's wedding picture: „A man with a really bad Elvis hairstyle and an Indian woman with a mile-high bouffant were kissing" [2000: 143]. They wished to have a traditional wedding and were married by a medicine man that was made to sing an Elvis song [2000: 144]. As Agnes Kramer-Hamstra notes, the author constructs Lisa ,in dialogue with both a resonant past and a present pop culture" [2009: 115], but the same is also true for other protagonists, such as Ma-ma-oo and Mick.

Hybridity is also manifest in the figure of B'gwus or sasquatch"the wild man of the woods" [Robinson 2000: 7], described as „not quite human, not quite wolf, but something in between" [2000: 374]. The B'gwus is presented from two different perspectives: as a creature from Haisla legend and as part of popular culture, which draws on local tales. The novel reports that „[h] is image is even used to sell beer 
[...] and the muddy impressions of very large feet keep B'gwus on the front page of tabloids and the cover of books which are dismissed as the results of overactive imaginations or imbibing too much alcohol or ingesting funky mushrooms" [2000: 317]. Not only is B'gwus depicted ,as another example of popular culture [it] is also associated with Haisla cultural values, spiritual power, and real terror" [Appleford 2005: 88]. The dual nature of B'gwus — human and animal—and its dual position in folklore and pop culture can be read from the underlying idea of the hybrid nature of the first Nations in Canada. Its ambiguous image resonates with the notion of the colonial exploitation of the First Nations and „echo[es] the dominant discourse's construction of North American Aboriginal peoples" [2005: 97]:

There are rumours that they [the B'gwus] killed themselves off, fighting over some unfathomable cause. Other reports say they starved to death near the turn of the century, after a decade of horrific winters. A variation of this rumour says they were infected with TB and smallpox, but managed to survive by leaving the victims to die in the woods. They are no longer sighted, no longer make dashes into villages to carry off women and children, because they avoid disease-ridden humans [Robinson 2000: 318].

Its position between folklore and popular culture is further fortified by its ambiguous position in the text, which posits it as a fictional being, but also implies that it might be real_-at least for Lisa, who sees it.

Images of popular culture in postcolonial texts play a salient role, representing the intrusion of the Other and denoting the zone of contact. Arundhati Roy and Eden Robinson both explore the negative consequences of colonialism and neocolonialism, and „offer counter-discourses to the dominant logos of metropolises" [Durix 1998: 187]. However, they employ images of popular culture in different ways. Roy interprets popular culture through the lens of neocolonial exploitation, and addresses the issue of globalisation and the repercussions it has precipitated on contemporary India, especially when she plays with the image of Coca-Cola, subverting its capitalis- 
tic symbolism and ideology in order to reveal the imposed Western consumerism and distribution of power. Her novel suggests ,that India's embracing of commodity culture and its consumerist ethic are responsible for an ongoing process of social fragmentation, environmental degradation, and decay, a process made apparent in the negative way in which American cultural forms and goods are depicted" [Lutz 2009: 60]. Though Robinson also acknowledges the detrimental results of colonisation in the form of the residential school system for the First Nations children and the processes of forced assimilation, which exerted a lasting traumatic effect, she examines popular culture within the framework of transculturation and hybridity. Popular culture informs the complex identity forged in postcolonial environments. The process of hybridisation is perceived as positive and necessary, for it, in Loomba's words, ,undercuts colonial hegemony" [2005: 149]. The incorporation of images of popular culture in postcolonial texts indicates the contact zone; they have strong ideological implications and function to subvert the accepted concepts of the centre and the margin. The language of popular culture and its imagery are thus a special topos and a literary device that gain powerful expressive force when employed by postcolonial authors, serving both as tools of decolonisation as well as a means of criticising global exploitation and neocolonialism.

\section{Literature}

Appleford R. [2005], "Close, very close, a b'gwus howls": The Contingency of Execution in Eden Robinson's Monkey Beach, "Canadian Literature" 184, 85-101, EBSCOHost. Web. [access 10.03.2012].

Ashcroft B., Griffiths G., Tiffin H. [1989], The Empire Writes Back. Theory and Practice in Post-colonial Literatures, Routledge, New York.

Durix J.-P. [1998], Mimesis, Genres and Post-Colonial Discourse. Deconstructing Magic Realism, Palgrave Macmillan, New York.

Fox C.L. [2002], A Martyrology of the Abject: Witnessing and Trauma in Arundhati Roy's The God of Small Things, "Ariel” 33.3/4, 35-60, Literature Resource Center, Web. [access 03.09.2011]. 
Goodman R. [2004], De-scribing the Centre: Satiric and Postcolonial Strategies in The Madonna of Excelsior, "Journal of Literary Studies" 20, 6270, Literature Resource Center. Web. [access 03.09.2011].

Kramer-Hamstra A. [2009], "Rumors of a Larger Story: The Intersection of Mystery and Mastery in Eden Robinson's Monkey Beach", "The Canadian Journal of Native Studies" 29.1/2, 111-125, ProQuest Social Science Journals. Web. [access 10.03.2012].

Loomba A. [2005], Colonialism/Postcolonialism, 2nd ed., Routledge, New York.

Lutz J. [2009], Commodity fetishism, patriarchal repression, and psychic deprivation in Arundhati Roy's The God of Small Things, "Mosaic (Winnipeg)" 42.3, 1-11, Literature Resource Center, Web. [access 03.06.2011].

Pratt M. L. [2008], Imperial Eyes. Travel Writing and Transculturation, 2nd ed., Routledge, New York.

Robinson E. [2000], Monkey Beach, Houghton Mifflin, New York.

Roy A. [1997], The God of Small Things, HarperCollins, London.

Wisker G. [2007], Key Concepts in Postcolonial Literature, Palgrave Macmillan, New York. 